\title{
Notes on types of three species of Scathophagidae (Diptera) described by I.W. Zetterstedt
}

\author{
Заметки о типах трех видов скатофагид (Diptera: Scathophagidae), \\ описанных И.-В. Џеттерштедтом
}

\begin{abstract}
A.L. Ozerov
A. $\Lambda$. Озеров

Zoological Museum, Moscow State University, Bol'shaya Nikitskaya 6, Moscow 125009, Russia. E-mail: ozerov2455@rambler.ru Зоологический музей, Московский государственный университет им. М.В. Ломоносова, Большая Никитская ул., 6, Москва 125009 , Россия.
\end{abstract}

KEY WORDS: Diptera, Scathophagidae, nomenclature, lectotype designation, new synonyms.

КЛЮЧЕВЫЕ СЛОВА: Diptera, Scathophagidae, номенклатура, обозначение лектотипа, новые синонимы.

ABSTRACT. Lectotype is designated for Cordylura filiformis Zetterstedt, 1846. Acerocnema breviseta (Zetterstedt, 1846) is raised from synonymy and is given new status as valid species. Four new synonyms are proposed: Acerocnema tiefi Becker, 1894 and Acerocnema pokornyi Becker, 1894 with Acerocnema breviseta (Zetterstedt, 1846), Scatomyza frontata Zetterstedt, 1838 with Staegeria kunzei (Zetterstedt, 1821), Micropselapha bohemica Barták et Kubík, 2012 with Micropselapha basovi Ozerov, 2010.

РЕЗЮМЕ. Обозначен лектотип для Cordylura filiformis Zetterstedt, 1846. Acerocnema breviseta (Zetterstedt, 1846) восстановлен из синонимов как валидный вид. Установлены 4 новых синонима: Acerocnema tiefi Becker, 1894 и Acerocnema pokornyi Becker, 1894 - новые младшие синонимы Acerocnema breviseta (Zetterstedt, 1846); Scatomyza frontata Zetterstedt, 1838 - новый младший синоним Staegeria kunzei (Zetterstedt, 1821); Micropselapha bohemica Barták et Kubík, 2012 - новый младший синоним Micropselapha basovi Ozerov, 2010.

\section{Introduction}

While studying flies of the family Scathophagidae I faced some difficulties which demanded the examination of type specimens. The types of three species described by Johan Wilhelm Zetterstedt and kept in Lund Univerity, Sweden (MZLU) were studied. The results of this work are given below.

\section{Results}

Cordylura breviseta Zetterstedt, 1846

breviseta Zetterstedt, 1846: 2022 (Cordylura) - stat. n. tiefi Becker, 1894: 155 (Acerocnema) - syn.n. pokornyi Becker, 1894:157 (Acerocnema) - syn.n.

Described from single female from "circa Hafniam". Holotype is pinned, is in very good condition, labelled "[?]62", "C. breviseta $q$ Staeger 41", "Holotypus Cordylura breviseta Zett. labelled 1954 by J.R. Vockeroth". Type-locality: Denmark, Northeast Zealand.

CURRENT IDENTITY: Acerocnema breviseta (Zetterstedt, 1846), stat. n.

REMARKS. Acerocnema breviseta is recognised by recent authors (e.g. Gorodkov [1986]; Šifner [2008];) as a synonym of Acerocnema macrocera (Meigen, 1826). However, both are good species. Scutum of $A$. macrocera is densely grey dusted (Fig. 1), and in $A$. breviseta is mostly shining (Fig. 4). There are differings in structure of genitalia (Figs 2, 3 and Figs 5, 6). Acerocnema tiefi Becker, 1894 and Acerocnema pokornyi Becker, 1894 proved to be new synonyms of $A$. breviseta.

\section{Cordylura filiformis Zetterstedt, 1846}

filiformis Zetterstedt, 1846: 2025 (Cordylura).

Described from female(?s) "in Suecia boreali". Two specimens were examined from MZLU. One of them (the abdomen is missing, otherwise it is in good condition) labelled " $\mathrm{C}$. filiformis + Lapp Lule" and "Lectotypus Cordylura filiformis Zett. Designated by J.R. Vockeroth 19" [not published]. I have labelled it and designate it herewith as lectotype, in order to fix the identity of the name filiformis. Type-locality: Sweden, Lule Lappmark. The second specimen - female in good condition, with a green tag, and label "Skalstug" has been labelled as paralectotype; it is conspecific with the lectotype.

CURRENT IDENTITY: Micropselapha filiformis (Zetterstedt, 1846), correctly recognised by recent authors. 


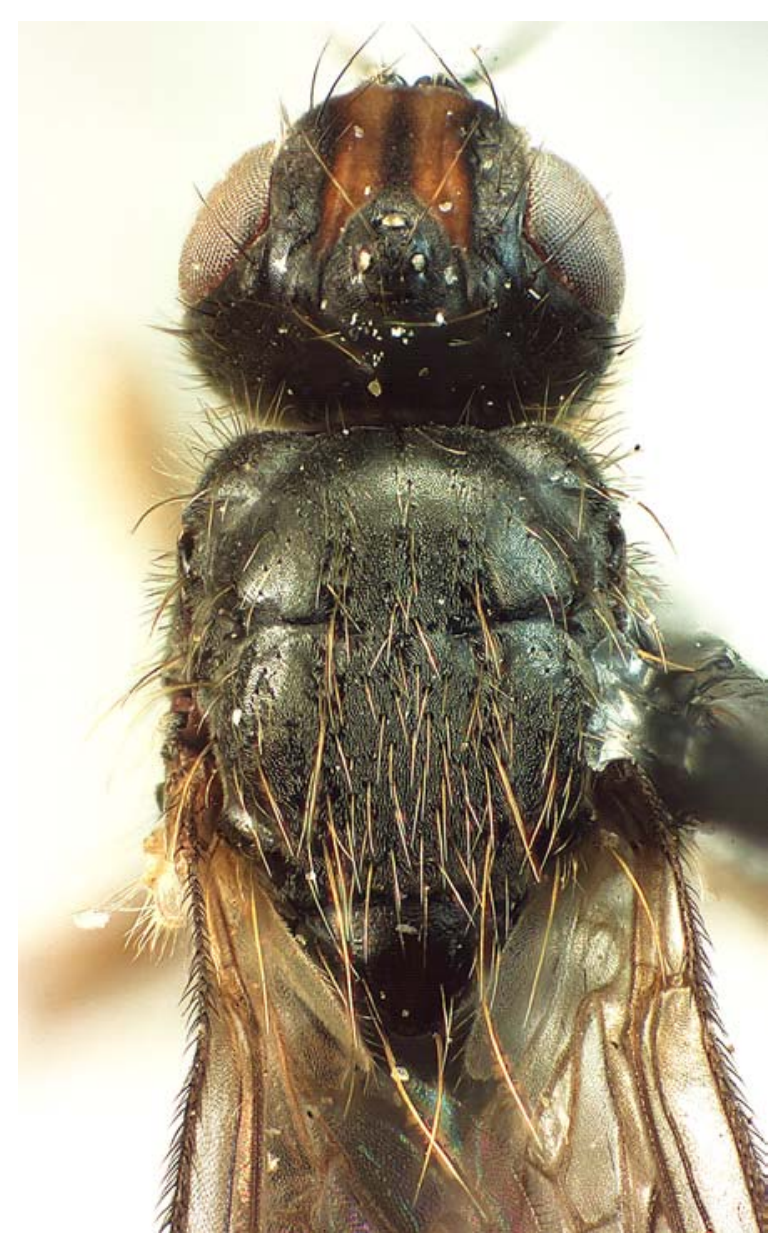

1

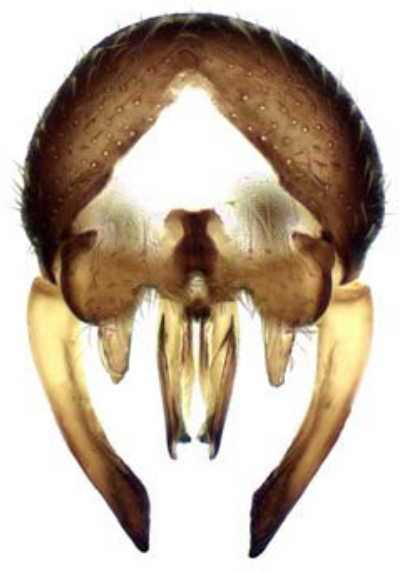

2

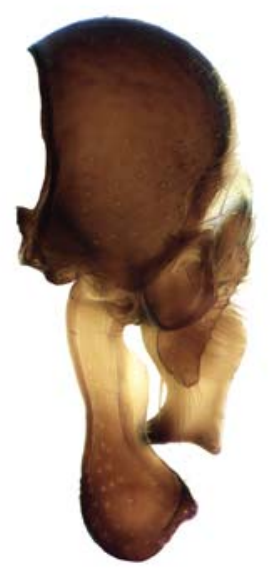

3

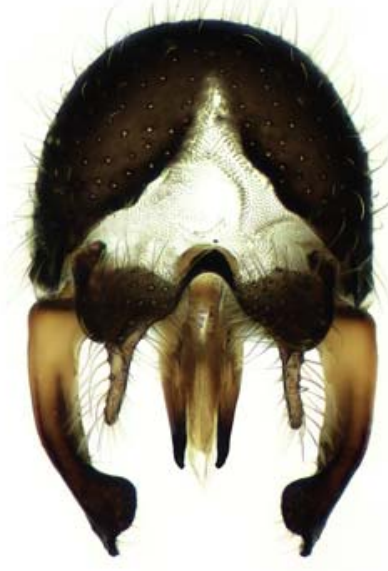

5

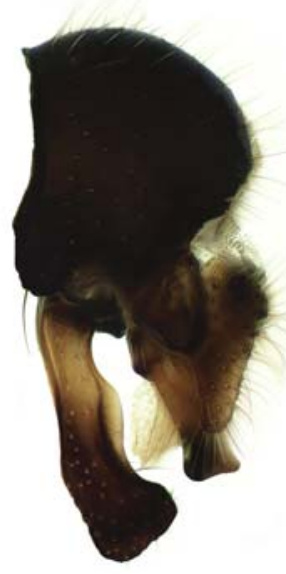

6

Figs 1-6. Acerocnema macrocera (Meigen, 1826) (1-3) and Acerocnema breviseta (Zetterstedt, 1846) (4-6), $\sigma^{7}: 1,4-$ scutum; 2, 5 - epandrium, cerci and surstyli, dorsal view; 3, 6- epandrium, cerci and surstyli, lateral view.

Рис. 1-6. Acerocnema macrocera (Meigen, 1826) (1-3) и Acerocnema breviseta (Zetterstedt, 1846) (4-6), О’: 1, 4- среднеспинка; 2, 5 - эпандрий, церки и сурстили, сверху; 3, 6 - эпандрий, церки и сурстили, сбоку. 


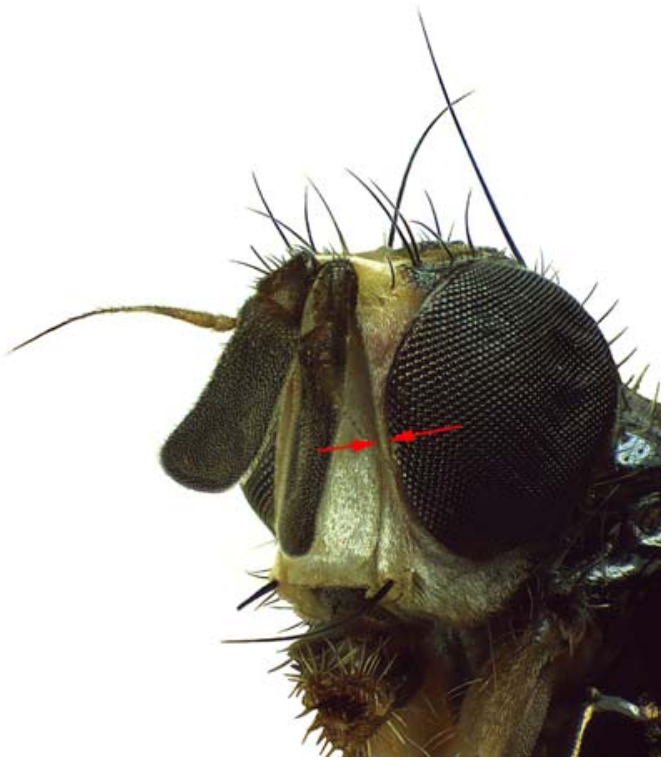

7

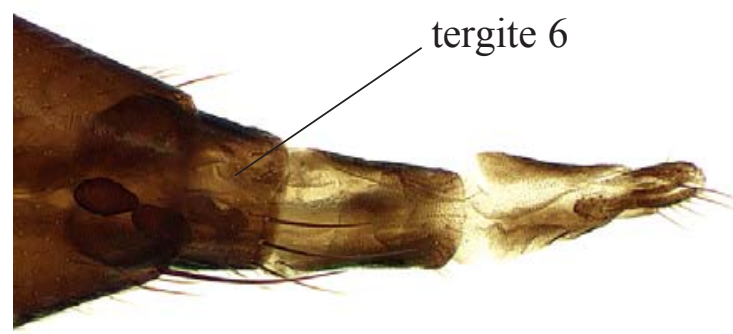

8

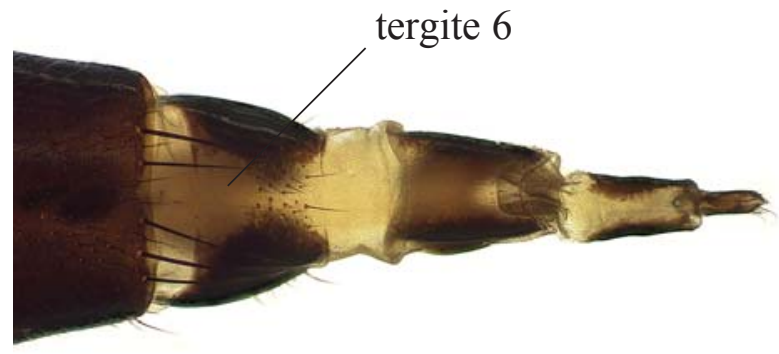

12

Figs 7-12. Micropselapha filiformis (Zetterstedt, 1846) $(7,8)$ and Micropselapha basovi Ozerov, 2010 (9-12): 7, 9- head; 8, 12 - end of female abdomen, dorsal view; 10, 11 - male sternite 5 .

9, 11 - holotype, 10 - $0^{7}$ from Novosibirsk reg.

Рис. 7-12. Micropselapha filiformis (Zetterstedt, 1846) $(7,8)$ и Micropselapha basovi Ozerov, 2010 (9-12): 7, 9 - голова; 8, 12 конец брюшка самки, сверху; 10, 11 - стернит 5 самца.

9,11 - голотип, $10-\mathrm{\sigma}^{7}$ из окр. Новосибирска.

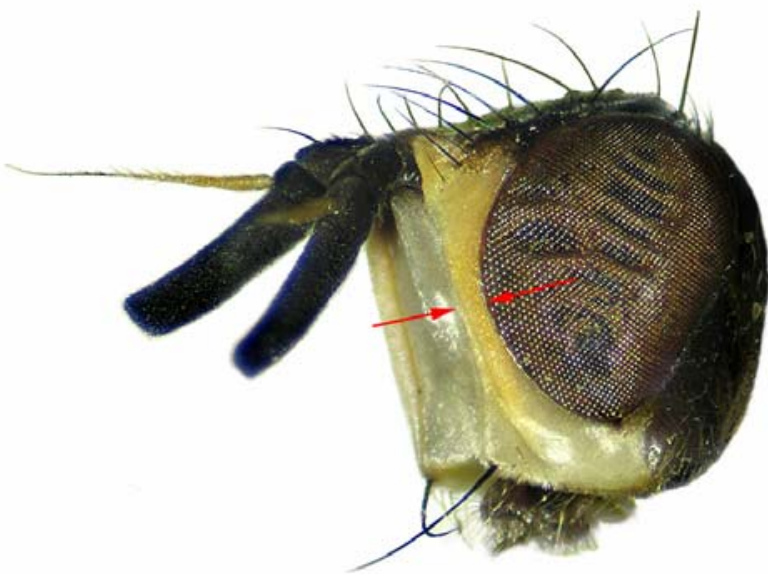

9

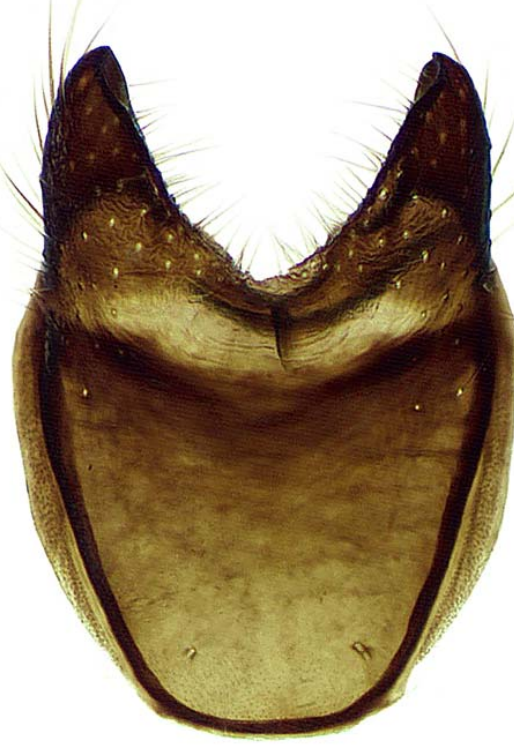

10

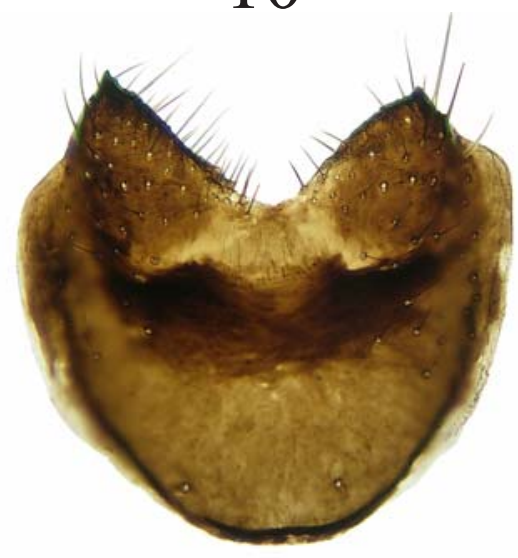

11 
REMARKS. The three species of the genus $\mathrm{Mi}$ cropselapha Becker, 1894 are currently known: $M$. filiformis, M. basovi Ozerov, 2010 and M. bohemica Barták et Kubík, 2012. M. basovi was described from single male from Tatarstan [Ozerov, 2010], M. bohemica was described from both sexes from Czech Republik and Slovakia [Barták \& Kubík, 2012].

I examined material of Micropselapha from Siberia: $\sigma^{7}$ labelled "Novosibirsk env. (ca. $54.8 \mathrm{~N}$ 83.1E), on Corydalis, 13.V.2012, leg. O. Kosterin" and $\sigma^{7}$ "Novosibirsk reg. (55.52 N 83.24 E), pine forest \& bog, 22.V.2011, leg. O. Kosterin (both in Zoological Museum, Moscow University), and numerous specimens from Czech Republik $\left(\sigma^{\top} \sigma^{\top}\right.$ and 00 , including paratypes of $M$. bohemica sent by Dr. M. Barták) in 2014. I determined all studied specimens as $M$. basovi.

The characters noted by Barták \& Kubík [2012: $106]$ for the differentiation of $M$. basovi and M. bohemica for my opinion are variations, exept for male sternite 5 . The latter is more likely undeveloped structure (Fig. 11), than variation (Fig. 10). So I consider $M$. bohemica to be the new synonym of $M$. basovi, syn.n.

M. filiformis differs easily from M. basovi by narrower parafacies (Fig. 7 and Fig. 9). Females of both species, as it was correctly noted by Barták \& Kubík [2012: 105, 106], differ easily by the structure of abdominal tergite 6. It is sclerotized completely in $M$. filiformis (Fig. 8), though in M. basovi is desclerotized in middle (Fig. 12).

\section{Scatomyza frontata Zetterstedt, 1838}

frontata Zetterstedt, 1838: 724 (Scatomyza).

Described from "unicum exemplar" from "Lapponia Tornensi ... in ripa fluminis ad Juckasjervi". Typelocality: Sweden, Torne Lappmark. Pinned. There are two specimens on pin. The upper is holotype of Scatomyza frontata (good condition), the lower is anthomyiid fly. Labels: "S. frontana + (Ar.[?An.] canescens $q$ ) Juckasjerv", "Holotypus Scatomyza frontata Zett. labelled 1954 by J.R. Vockeroth".
CURRENT IDENTITY: A junior synonym of Staegeria kunzei (Zetterstedt, 1821), syn.n.

REMARKS. Gorodkov [1986: 24] placed this species in the genus Microprosopa Becker, 1894, possibly, following Hackman [1956: 57]. However it remained unclear why Gorodkov [1986: 24] mentioned Cordylura strigifrons Zetterstedt, 1838 [Gorodkov, 1986: 24] as a synonym of this species. The type of $C$. strigifrons needs examination.

ACKNOWLEDGEMENTS. It is pleasure to thank the curator, Rune Bygebjerg (Lund), who loaned me the type material. Also I wish to thank Miroslav Barták (Praha) for material of Micropselapha from Czech Republik, including paratypes of $M$. bohemica. Finally my thanks go to Verner Michelsen (Copenhagen) for his help with reading text on some labels.

\section{References}

Barták M., Kubík Š. 2012. A redefinition of Micropselapha Becker, 1894 (Diptera, Scathophagidae) with description of a new species from Central Europe // Entomological News. Vol.123. No.2. P.101-109.

Becker T. 1894. Dipterologische Studien. I. Scatomyzidae // Berliner Entomologische Zeitschrift. Bd.39. H.1. S.77-196.

Gorodkov K.B. 1986. Family Scathophagidae // Soós Á., Papp L. (eds.). Catalogue of Palaearctic Diptera. Vol.11. Scathophagidae-Hypodermatidae. Budapest: Akadémiai Kiadó. P.1141.

Hackman W. 1956. The Scatophagidae (Dipt.) of Eastern Fennoscandia // Fauna fennica. Helsingforsiae: Societas pro Fauna et Flora Fennica. Vol.2. 67 pp.

Ozerov A.L. 2010. Five new species of Scathophagidae (Diptera) from Russia // Russian Entomological Journal. Vol.19. No.2. P. 157-166.

Šifner F. 2008. A catalogue of the Scathophagidae (Diptera) of the Palaearctic region, with notes on their taxonomy and faunistics // Acta Entomologica Musei Nationalis Pragae. Vol.48. No.1. P.111-196.

Zetterstedt J.W. [1838]. Sectio tertia. Diptera // Insecta Lapponica. '1840'. Lipsiae [= Leipzig]: Leopold Voss. P. 477-868

Zetterstedt J.W. 1846. Diptera Scandinaviae disposita et descripta. Tomus quintus. Lundae [= Lund]: Ex officina lundbergiana. P.1739-2162. 